\title{
Wstęp
}

\section{Między sztuką a rzemiosłem.}

\section{„Napis”: początki, dzieje, aktualności}

W jubileuszowym, XXV numerze czasopisma „Napis. Pismo poświęcone literaturze okolicznościowej i użytkowej”, zatytułowanym Pamiatka, botd, laudacja w literaturze $i$ kulturze, przed wprowadzeniem do lektury artykułów tu zawartych pragniemy poświęcić nieco uwagi jego założycielowi i animatorowi, wieloletniemu (od 1994 do 20II roku) Redaktorowi Naczelnemu rocznika, Profesorowi Januszowi Maciejewskiemu, a zarazem pokrótce przypomnieć kontekst narodzin i funkcjonowania „Napisu”.

Czasopismo zainicjował Profesor w 1994 roku, w podtytule umieszczając informację na temat jego profilu: „Tom poświęcony literaturze okolicznościowej i użytkowej”. Członkami pierwszego składu redakcji obok Redaktora Naczelnego byli: Anna Błaszkiewicz, Stanisław Dubisz, Agnieszka Dorota Kawka, Zofia Rejman, Katarzyna Sałkiewicz, Janusz Tazbir i Jacek Wójcicki (sekretarz redakcji). Grono to skupiało nie tylko literaturoznawców i językoznawców, lecz również historyków, socjologów i kulturoznawców, co podkreślił Janusz Maciejewski - autor wprowadzenia do rozpraw opublikowanych w pierwszym tomie, pod tytułem Literatura okolicznościowa i użytkowa (Zamiast wstępu). Akcentował w nim, że poza obszarem dotychczasowej szczegółowej refleksji badawczej, w efekcie rozmaitych dokonywanych w ostatnim czasie przewartościowań, w XX wieku znalazło się „zarówno [...] piśmiennictwo polityczne, historyczne czy kaznodziejstwo, jak i nowe formy kultury masowej, czy wreszcie liczne zjawiska, zawsze znajdujące się na marginesach literatury wysokiej i folkloru” („Napis” I, s. 3). Badacz przypomniał również, że ten niepokojący stan rzeczy sygnalizował już kilka lat wcześniej (przed wydaniem pierwszego tomu czasopisma), gdy opisywał 
i próbował uporządkować pograniczne fenomeny literackie mieszczące się (jak to określił) na obszarach trzecich literatury.

Profesor Maciejewski zwrócił uwagę na wartość obszernego działu piśmiennictwa okolicznościowego, będącego swoistym świadectwem czasów, w których powstawały utwory dotyczące aktualnych spraw publicznych i zdarzeń prywatnych oraz różnorodne teksty użytkowe. Tego rodzaju literatura z obszarów pozostających wówczas poza zainteresowaniami badaczy stanowiła przedmiot naukowych rozważań przede wszystkim $\mathrm{w}$ aspekcie reakcji na ważne wydarzenia polityczne związane z polską i europejską zbiorowością. Nie można było jednak ograniczać się jedynie do tego aspektu, należało poszerzyć zakres badań.

We wprowadzeniu do rozpraw zawartych w tomie oraz $\mathrm{w}$ dołączonych doń przypisach Profesor zaznaczył i docenił fakt, że i w XIX, i w XX stuleciu nie brakowało chlubnych wyjątków od reguły pomijania tych fenomenów literatury. Wyrazem uznania dla dokonań XX-wiecznych uczonych dowartościowujących już wcześniej ten rodzaj piśmiennictwa (między innymi Teodora Wierzbowskiego, Karola Badeckiego, Jana Czubka, Juliana Krzyżanowskiego, Stefanii Skwarczyńskiej, Władysława Włocha, Kazimierza Kolbuszewskiego, Juliusza Nowaka-Dłużewskiego, Antoniny Kłoskowskiej) i badających je w różnych aspektach (historycznym, socjologicznym, kulturowym, rzadziej historycznoliterackim) było nawiązanie $\mathrm{w}$ nazwie nowo utworzonego rocznika do tytułu pracy jednego $\mathrm{z}$ tych badaczy - Jana Stanisława Bystronia: Napisy. Drobiazgi tradycyjne (1927).

Wyróżnikiem szczególnym i specjalnością pisma była więc od samego początku literatura zajmująca szeroką przestrzeń między twórczością wysokoartystyczną a produkcją literacką amatorów i autorów minorum gentium; między sztuką a rzemiosłem, między pisarstwem autorskim a folklorem środowiskowym, często bezimiennym. Łączyło się to wyraźnie z zainteresowaniami naukowymi Profesora Janusza Maciejewskiego - niestrudzonego badacza obszarów trzecich literatury oraz uczonego opisującego cechy tego rodzaju piśmiennictwa i odkrywającego nierozpoznane dotąd przejawy folkloru środowiskowego - utwory powstałe w różnych epokach, lecz posiadające liczne cechy wspólne.

Szczególnie interesował Profesora folklor szlachecki, jego znamiona i przejawy długo współistniejące na granicy sarmatyzmu oraz nowej, oświeceniowej świadomości i kultury estetyczno-literackiej. Było to naturalne u autora od lat zajmującego się naukowo wieloma epokami literackimi, początkowo zwłaszcza przełomem między romantyzmem a pozytywizmem (w książce Przedburzowcy, Warszawa 1971), jednak w sposób szczególny fascynującego się okresem oświecenia jako niejednorodną - sarmacko-oświeceniową - formacją kulturową. Oświecenie traktował jako czasy wieloaspektowego przełomu, nie tylko konfrontacyjnego, dychotomicznego (jak 
to często ujmowano, postrzegając proces historyczny jako przezwyciężanie opcji konserwatywnych przez czynniki postępowe). Profesor zaznaczał, że były to również czasy wspólistnienia przez wiele lat nowych, postępowych pierwiastków i elementów wywodzących się z przebogatej tradycji sarmatyzmu, zakorzenionych w umysłach szlacheckiej społeczności. Porozumienie czy dialog między tymi elementami kultury nie były łatwe, jako że różnice i napięcia zaowocowały ostrą dychotomią społeczeństwa polskiego (zwłaszcza na początku wspomnianego okresu). Profesor Maciejewski pisał jednocześnie, że w badaniach naukowych rozpoznawanej przez niego formacji kulturowej (a w istocie dwóch formacji) warto zwrócić również uwagę na współistnienie poglądów, idei, a także między innymi na współdziałanie „starych” literatów z pisarzami nowego formatu w rozmaitych przedsięwzięciach kulturalnych i literackich, na obecność różnorodnych ujęć artystyczno-literackich. Nie należy natomiast skupiać się wyłącznie na - bez wątpienia ważkich - różnicach ideologicznych, kulturowych i psychologicznych (które notabene akcentował w głównym wywodzie). Wnikliwe, pionierskie wówczas rozpoznanie tak rozumianej oświeceniowej i sarmackiej formacji dał Janusz Maciejewski w swojej książce Dylematy wolności. Zmierzch sarmatyzmu i poczatki oświecenia w Polsce, opublikowanej w tym samym roku, co pierwszy tom stworzonego przezeń „Napisu” (1994).

Przypomnijmy ponadto, że Profesor zajmował się szczególnie poezją, ale także prozą okolicznościowo-polityczną drugiej połowy XVIII stulecia (w kilku rozprawach, w których prowadził dialog z innymi badaczami utworów $\mathrm{z}$ tego zakresu: Edmundem Rabowiczem i Romanem Kaletą, oraz w antologii Literatura barska wydanej w serii I Biblioteki Narodowej w 1976 roku). Tym badaniom, dotyczącym początkowo spornej terminologii, wyodrębniania i wytyczania działów tego piśmiennictwa, formułowania potrzeb badawczych, a w późniejszym czasie - wyznaczonych obszarów, Janusz Maciejewski poświęcił kilkadziesiąt lat swojego życia. Potrafił też skupić wokół siebie grono młodych adeptów nauki doceniających kulturową, historyczną i literacką wartość tekstów okolicznościowych. W czterotomowym wydaniu Literatury konfederacji barskiej, monumentalnym dziele zespołu badaczy, opublikowanym w latach 2005-2009 (pod Jego kierownictwem oraz pod redakcja Agnieszki Bąbel, Agaty Grabowskiej-Kuniczuk i Jacka Wójcickiego) zostały ukazane bogactwo tematyczne oraz różnorodność form gatunkowych i ujęć estetycznych pism literackich, które powstały w dramatycznych dla szlacheckiej Rzeczypospolitej latach 1768-I772 oraz na przedpolu tych burzliwych wydarzeń krajowych w I767 roku (t. I: Dramaty - 2005, t. II: Dialogi-2005, najobszerniejszy t. III: Wiersze - 2008, obejmujący około 250 utworów, mających walor źródłowy, zwłaszcza dla historyków, ale również mogących stanowić obiekt badań dla historyków, teoretyków i socjologów literatury, wreszcie t. IV: Silva rerum - 2009, zawierający nieznane 
dotąd dokumenty, między innymi z zakresu historii wojskowości, oświetlające poczynania i decyzje władz ruchu barskiego różnego szczebla). Ta kilkutomowa monografia - edycja krytyczna tekstów źródłowych - wypełniała lukę w wiedzy o życiu i klimacie kulturowym dawnej Rzeczypospolitej, a zwłaszcza o świadomości ówczesnego społeczeństwa. Jednocześnie uzupełniała historię literatury polskiej o obszary różnych form literackich kultury oficjalnej, funkcjonujących w obiegach folkloropodobnych obok form specyficznych, nieznanych kulturze wysokiej.

Wraz z upływem lat czasopismo „Napis” przestało ograniczać się do obszarów trzecich literatury, rozumianych początkowo jako przejaw swoistego, niedocenianego w dotychczasowych pracach naukowych, folkloru środowiskowego, którego nie powinno się pomijać, a przeciwnie - który należy uwzględnić w badaniach. To był jednakże dopiero pierwszy, choć arcyważny krok!

Rozległe badania, publikacje i inicjatywy naukowe Profesora Janusza Maciejewskiego oraz Jego współpracowników na rzecz literatury okolicznościowej i użytkowej pobudziły historyków i teoretyków literatury oraz badaczy reprezentujących pokrewne dziedziny nauk humanistycznych (językoznawstwa, historii, socjologii, antropologii kultury). W kolejnych seriach „Napisu” publikowane były artykuły, w których dokonywano precyzyjnego opisu i wielostronnie rozważano utwory z zakresu piśmiennictwa okolicznościowego, okazjonalno-towarzyskiego i użytkowego. Tym samym poszerzano badane obszary o nowe teksty lub na nowo interpretowano teksty znane. Pozwoliło to traktować coraz bardziej rozległe przestrzenie narodowego piśmiennictwa wielu epok jako przejaw tego rodzaju literatury. Okazało się ponadto, że autorami tych utworów byli nie tylko ukrywający swoje nazwisko lub mało znani pisarze, lecz również twórcy prominentni. $\mathrm{O}$ ich tekstach mających znamiona okolicznościowości wiedziano i od dawna były one przedmiotem zainteresowania, lecz uważne spojrzenie na niektóre $z$ nich (głównie przez ten nowy pryzmat badawczy) pozwoliło dokonywać odkrywczych rozpoznań ich niedocenianych lub zgoła niedostrzeganych dotąd funkcji artystycznych i społecznych. Niektóre z tych funkcji i znaczeń ujawniały się niekiedy dopiero przy porównaniu licznych tekstów na dany temat lub powstałych w tymże czasie, a tworzonych przez mniej znanych lub anonimowych autorów. Dodajmy, że swoista nobilitacja okolicznościowości i użytkowości umożliwiała również szersze niż dotąd poświęcenie uwagi znajdującym się w dorobku uznanych pisarzy dziełkom niedokończonym, zarzuconym w trakcie pisania, a także nadawała sens wydobywaniu ze zbiorów archiwalnych - publicznych i prywatnych - dokumentów osobistych: listów, dzienników, pamiętników, zapisków brulionowych i tym podobnych źródłowych świadectw ich życia i twórczości. Pozwalało to między innymi wskazać oryginalny materiał i otoczkę wielu użytych przez autorów wątków i motywów literackich, dokładniej poznać ich 
osobowość, fascynacje, obawy, funkcjonowanie w życiu codziennym, rodzinnym, towarzyskim - przeanalizować czynniki mające niebagatelny wpływ na rozważaną $\mathrm{w}$ dotychczasowych badaniach twórczość tych pisarzy.

Rozproszone wysiłki historyków i teoretyków literatury, socjologów, historyków, badaczy kultury materialnej, obyczajowej oraz innych pokrewnych dyscyplin naukowych, dotyczące utworów tego rodzaju, wraz z powstaniem „Napisu” mogły zostać scentralizowane w kolejnych tomach czasopisma, którego cechą stało się interdyscyplinarne podejście do tej twórczości, a zarazem równe traktowanie różnorodnych tekstów należących do kultury piśmienniczej społeczeństwa.

Profesor Janusz Maciejewski już wcześniej, w okresie przed opublikowaniem pierwszego tomu czasopisma, jako założyciel dwóch bliźniaczych jednostek naukowo-badawczych, kierowanych przez Niego: Pracowni Literatury Okolicznościowej i Użytkowej UW i Zespołu Badań Obszarów Trzecich Literatury IBL PAN, a także w trakcie ich działalności, inspirował środowisko naukowe. Podkreślano tu znaczenie tej literatury, godnej szczególnej uwagi między innymi jako wielogłos różnego rodzaju środowisk społecznych, politycznych i towarzyskich oraz świadectwo różnorodnych perspektyw w widzeniu aktualnych wydarzeń krajowych i spraw prywatnych. W aspekcie społeczno-politycznym były to głosy reprezentujące stanowisko ówczesnej władzy lub, wręcz odwrotnie - nieskrępowane oficjalną cenzurą. Natomiast w aspekcie środowiskowym - czy węziej: towarzyskim - chodziło najczęściej o różnego rodzaju zapisy prywatne, przeznaczone dla członków rodziny lub przyjaciól. $Z$ satysfakcją należy podkreślić, iż obecnie stanowią one obiekt zainteresowania wydawców naukowych (w edycjach tradycyjnych i cyfrowych), a także - co za tym idzie - interpretatorów piśmiennictwa intymistycznego. Okazują swą wagę nie tylko jako dokumenty osobiste, wyjaśniające zarówno ważne fakty z biografii ich autorów, jak i oświetlające ich twórczość czy życie codzienne, ale jako źródła historyczno-literackie, które uświadamiają wartość i nieznane dotąd rozmiary pewnych nurtów narodowego piśmiennictwa.

Zderzenie oficjalności i niezależności poglądów, wyrażanych opinii oraz emocji okazywało się szczególnie interesujące. Pozwalało dokładniej, bardziej szczegółowo i wnikliwie opisać opinie i nastroje zbiorowości panujące w danym okresie, poznać kulisy ówczesnych wydarzeń publicznych, a także różnorodne powiązania znanych lub wydobywanych $\mathrm{z}$ zapomnienia postaci (w tym literatów) $\mathrm{z}$ innymi osobami publicznymi lub prywatnymi, refleksje i opisy zainspirowane miejscami zwiedzanymi podczas zagranicznych albo krajowych podróży, osobiste wzruszenia. Wszystko to odzwierciedlały zarówno stopniowo, coraz częściej publikowane w krytycznych edycjach przez znawców tematu utwory literackie, jak i dokumenty osobiste (pamiętniki, wspomnienia, listy) odkrywane w zbiorach archiwalnych. Powstawała 
podstawa monograficznych lub cząstkowych prac historycznoliterackich. Poznawane dzięki tym wydaniom i uwzględniane w badaniach piśmiennictwo okolicznościowe oraz teksty użytkowe (na przykład afisze teatralne, ogłoszenia prasowe, bilety powiadamiające o odbywanych wizytach) stawały się nie tylko ważnym źródłowym dokumentem życia politycznego oraz obyczajowego i konwencji kulturowych, a także form życia towarzyskiego, popularnych rozrywek, modnych przyjemności i towarzyszących im relacji, lecz i argumentem na rzecz formułowanych nowych rozpoznań dotyczących danej epoki - rozpoznań obejmujących szersze niż dotąd spektrum czynników.

W Pracowni Literatury Okolicznościowej i Użytkowej UW oraz w Zespole Badań Obszarów Trzecich Literatury IBL PAN prowadzono rozległe badania źródeł $\mathrm{z}$ różnych epok, organizowano regularne spotkania naukowe, wygłaszano odczyty i dyskutowano zagadnienia związane między innymi z tematyką prezentowanych utworów literackich, sposobem ich rozpowszechniania, różnorodnością wykorzystywanych form artystycznych, zabiegów (perswazji, persyflażu, krytyki, pochwały i tym podobnych) stosowanych przez autorów dla oceny wydarzeń i osób publicznych lub postaci mniej znanych, lecz mających wpływ na życie określonych środowisk. Rozważano też problemy chronologii i atrybucji autorskich, zwłaszcza w przypadku tekstów szczególnie głośnych, wywołujących szeroki odzew zaświadczony na przykład liczbą oficyn wydawniczych decydujących się na ich publikację, liczbą druków (w tym także ulotnych) czy kopii rękopiśmiennych - odniesień (refutacji lub akceptujących przywołań). Były to pasjonujące świadectwa recepcji czytelniczej, ale nie tylko. Te okolicznościowe, okazjonalne i użytkowe pisma posiadały również niekwestionowane walory artystyczne oraz udokumentowany wpływ na inne, bardziej znaczące teksty, a - tym samym - zarówno na rozmiary toczonych dyskursów, kluczowych dla ówczesnej zbiorowości, jak i na kształtowanie się ogólnych poglądów o sprawach prywatnych i obyczajowych. Ukazywały klarowanie się przeróżnych opinii o bieżących i o przeszłych wydarzeniach oraz ich uczestnikach, zaciekawiały bogactwem stosowanych zabiegów i chwytów estetyczno-literackich, rodzajem refleksji i argumentacji. I choć zapewne przede wszystkim utwory najbardziej wartościowe pod względem artystycznym i tworzone $\mathrm{z}$ uwagi na motywacje ogólnokulturowe przyczyniały się w danym okresie do utrwalania nowych myśli i idei, to równie interesujące jako obiekt badań okazywały się te dotąd często nieznane teksty, w których przeważały motywacje prywatne, osobiste lub w których niebagatelna była rola tradycji, skutkująca wielokroć powielaniem utrwalonych wzorów.

Wzrastająca wśród przedstawicieli nauk humanistycznych świadomość tego rozpoznania była kolejnym ważnym krokiem zachęcającym do skupiania się wokół 
„Napisu” badaczy z różnych instytutów naukowych i uczelni - zarówno uznanych autorytetów, reprezentujących starsze pokolenie, jak i młodszych adeptów humanistyki, którym otwarto drogę do ukazania odbiorcom czasopisma rzetelnych wyników ich początkowych namysłów, kwerend oraz formułowania argumentów z dołączoną doń dokumentacją. Rola dokumentu bowiem była w „Napisie” właściwie od samego początku istnienia pisma bardzo ceniona. Zawartość działu Rozprawy została dość szybko rozszerzona i zaczął on obejmować Rozprawy i materiaty. Te „materiały” stanowiły wartościowe zalążki części wydzielonej w późniejszych latach istnienia czasopisma, gromadzącej edycje krytyczne tekstów źródłowych (zwykle niewielkich rozmiarów). Były to dokumenty różnego rodzaju: między innymi historyczne, odnoszące się do minionych dziejów lub niedawnej przeszłości; osobiste, związane $\mathrm{z}$ mniej lub bardziej znanymi postaciami narodowej kultury; nieznane utwory literackie prozatorskie i poetyckie. Edycje te poprzedzano syntetycznym wstępem stanowiącym wprowadzenie do ich lektury.

Niektóre tomy „Napisu” zapełniały prace nadesłane przez autorów biorących udział w interdyscyplinarnych konferencjach naukowych. Były to rozprawy i studia omawiające na wybranych przykładach temat wskazany przez organizatorów związanych $\mathrm{z}$ czasopismem oraz $\mathrm{z}$ dwoma wymienionymi instytucjami (PLOiU i ZBOTL). Tematy konferencji rozwijające wybrane problemy literatury okolicznościowej i użytkowej zwykle wiązano $\mathrm{z}$ wydarzeniami istotnymi dla przeszłości narodu. Te projekty naukowe realizowano dzięki współdziałaniu Pracowni Literatury Okolicznościowej i Użytkowej Instytutu Literatury Polskiej UW oraz Zespołu Badań Obszarów Trzecich Literatury Instytutu Badań Literackich PAN z wydatnym udziałem członkiń redakcji „Napisu”: Agnieszki Bąbel i Agaty Grabowskiej-Kuniczuk, przy szczególnie aktywnym zaangażowaniu Jacka Wójcickiego, najpierw sekretarza redakcji, potem zaś zastępcy redaktora naczelnego. Uczestnikami konferencji organizowanych przez członków redakcji czasopisma we współpracy z wieloma ośrodkami naukowo-badawczymi w kraju, między innymi Książnicą Cieszyńską, Uniwersytetem Jana Kochanowskiego w Kielcach, Uniwersytetem imienia Adama Mickiewicza w Poznaniu, Uniwersytetem Przyrodniczo-Humanistycznym w Siedlcach, byli badacze krajowi i zagraniczni, zarówno doświadczeni, jak i dopiero debiutujący, a rocznik „Napis” stanowił główną trybunę rozpowszechniania prezentowanych na tych naukowych spotkaniach rozważań intertekstualnych, wyników badawczych poszukiwań i prowadzonych dyskusji.

Wspomniane konferencje oprócz wymiernych rezultatów, udokumentowanych kolejnymi tomami „Napisu”, dawały okazję do integracji środowiska humanistycznego z pokrewnych dziedzin (literaturoznawstwo, językoznawstwo, historia, socjologia, antropologia, kulturoznawstwo, komunikacja społeczna i tak dalej) z różnych 
krajowych i międzynarodowych ośrodków. Przyczyniły się do wymiany doświadczeń oraz do rozwoju naukowego zwłaszcza młodych przedstawicieli nauki, przez ich uczestnictwo w konferencjach naukowych oraz w oficjalnych czy nieformalnych dyskusjach związanych $z$ tymi spotkaniami. $W$ ich wyniku podejmowano rozmaite naukowe prace zespołowe, powstawały też publikacje prezentowane w „Napisie”.

Efekty tego rozwiązania owocowały nie tylko pod względem badawczym, lecz również czytelniczym. Gwarantowały monograficzny, zwarty charakter kolejnych roczników czasopisma, co zwykle spotykało się z szerokim odzewem. Warto tu wspomnieć o wybranych seriach, których główna zawartość była pokłosiem zaplanowanych $z$ rozmysłem i specjalnie zorganizowanych konferencji naukowych. Serie te wywołały duże zainteresowanie odbiorców pisma. Należy tu koniecznie wymienić następujące tomy: Bellona, Klio, Kamena... Literatura wobec wojen („Napis” VII); „Grzeczność nie jest naukq tatwq ani mata”. Formy i normy stosowności („Napis” X); Stowa ponad granicami. Literackie świadectwa kontaktów kulturowych („Napis” XI); Krzywe zwierciadto na gościńcu. Literacka satyra, karykatura, groteska („Napis” XIV); Umysty zniewolone. Literatura pod presja („Napis” XV) oraz szczególnie tom bardzo dobrze oceniany: Literatura i rytuaty („Napis” XVI). Ten ostatni rocznik dotyczył bowiem nie tylko swoistej „rytualności” literatury i form rytuałów zapisanych w utworach literackich, ale też tych obecnych od wieków w kulturze, a ocalałych wielokroć (gdy zanikały w obyczajowości) dzięki tekstom pisanym i rozpoznaniom tych śladów przez badaczy różnych dziedzin nauki.

Późniejsze numery czasopisma nie były już powiązane z organizowanymi konferencjami naukowymi, lecz członkowie redakcji i Rady Naukowej dążyli do tego, aby każdy z nich w dalszym ciągu składał się z artykułów, którym zwartość nadawał podany na stronie czasopisma temat, co pozwalało zachować monograficzny charakter oferowanych czytelnikom tomów. Na szczególną uwagę zasłużyły takie $\mathrm{z}$ roczników, jak ten poświęcony osobie i dokonaniom założyciela, Profesora Janusza Maciejewskiego, zatytułowany Jawne i ukryte w literaturze i kulturze („Napis”XVII).

Na uwagę zasługują też z całą pewnością numery: Tabu i wstyd („Napis”XVIII), nawiązujący do poprzedzającego go rocznika Jawne i ukryte w literaturze $i$ kulturze, ale $\mathrm{z}$ większą jeszcze odwagą podejmujący zagadnienia tabuizacji, odsłaniający sprawy ukryte w kulturze oficjalnej i ukazujący różne sposoby przełamywania tabu, a także tom List jako szczególny gatunek literacki... („Napis”XXIII), również częściowo wiążący się z bezpruderyjnym odsłanianiem osobistych realiów z życia pisarzy, wyłaniających się $z$ ich korespondencji, prezentowania nieznanych fascynacji, lęków, obaw, radości. Było to w dużej mierze świadectwo „łamania pieczęci” przez badaczy dokumentów osobistych, do których dzięki swym poszukiwaniom 
dotarli, które częstokroć planowali wydać, dążąc do pełnego poznania danego twórcy i jego środowiska, a przed ukończeniem edycji wysnuwali już pewne wnioski wynikające $z$ badań. Szczególnie ważny wydaje się też tom poprzedzający numer jubileuszowy pisma pod tytułem Nie tylko wiersz, nie tolko roman. Literatura polska i rosyjska w kontekście gatunków literackich („Napis”XXIV), zawierający rozważania badaczy rosyjskich i polskich, zredagowany pod kierunkiem Marka Pąkcińskiego według jego pomysłu i dzięki zainspirowaniu polskich oraz zagranicznych badaczy rosyjskiej literatury i kultury, z którymi jako organizator licznych konferencji nawiązał kontakty naukowe, będąc dyrektorem Stacji Naukowej PAN w Moskwie (w latach 2015-2018).

Gdy we wstępie do jubileuszowego rocznika Hotd, laudacja, pamiatka w literaturze $i$ kulturze wspominamy i upamiętniamy zwłaszcza osoby niezwykle ważne dla czasopisma, to koniecznie należy tu przypomnieć rocznik pisma pod tytulem wybranym jak zawsze nieprzypadkowo: Warunkiem trwatości jest przemiana. Kontynuacje, parafrazy i aluzje literackie („Napis”XXII). Tom upamiętniał osobę wybitnego historyka Profesora Janusza Tazbira, który od I994 roku, jako członek redakcji pierwszego tomu „Napisu”, aktywnie wspólpracował z periodykiem przez wszystkie te lata, będąc członkiem redakcji, konsultantem oraz doradcą i przyjacielem czasopisma. Jako członek Rady Naukowej „Napisu” Profesor Tazbir proponował interesujące rozwiązania, był między innymi projektodawcą samodzielnego działu pisma Pasje i potyczki edytorskie i tekstologiczne (od numeru XIX). Uznał za godny szczególnej uwagi problem szeroko rozumianego błędu w utworach, ich edycjach i generalnie - w badaniach naukowych. Problem ten pragniemy postawić jako temat przewodni kolejnego XXVI „Napisu”: „Errare humanum est”. Btędy w naukach bumanistycznych, ich rodzaje $i$ konsekwencje (zob. www. napis.edu.pl). Zmierzamy do tego, aby planowany numer „Napisu” zgromadził teksty badaczy z różnych dziedzin nauki: historyków dziejów, edytorów tekstów źródłowych, historyków i teoretyków literatury, językoznawców, kulturoznawców oraz tłumaczy, a także redaktorów posiadających dużą praktykę w zakresie przygotowywania zarówno monografii indywidualnych lub zbiorowych, jak i czasopism naukowych oraz podobnych publikacji, którzy w swych „prześwietleniach” danego tekstu borykali się z omyłkami występującymi w nadesłanych przez autorów materiałach i dążyli do optymalnego finalnego efektu.

Zakres chronologiczny studiów i rozpraw opublikowanych w wymienionych powyżej i w innych tomach „Napisu” sięgał zwykle od literatury i kultury staropolskiej po literaturę i kulturę XX i XXI wieku (tu na przykład podejmowano kilkakrotnie zagadnienia coraz bardziej powszechnych edycji cyfrowych tekstów). W aspekcie genologicznym zawarte w rocznikach prace reprezentowały: twórczość 
poetycką (pieśń żołnierska, pobudka, odezwa, oda, list poetycki, liryk funeralny, panegiryk, pamflet i paszkwil i tym podobne); dramat (na przykład komedia rybałtowska, okolicznościowy dramat alegoryczny, opera); prozę wspomnieniową i epistolarną wydobywaną przez autorów (podobnie jak liczne omawiane czy edytowane wiersze) z rękopisów, starodruków i późniejszych ineditów; reportaż (i jego zaczątki) oraz inne gatunki użytkowe (kazania, mowy, kalendarze, poradniki, instrukcje).

Obok artykułów przyczynkarskich i edycji nieznanych tekstów poprzedzonych wstępem były to również odkrywcze badawczo rozprawy o charakterze analityczno-interpretacyjnym i studia naukowe - historycznoliterackie i historyczne, socjologiczne, kulturoznawcze, a nawet muzykologiczne. Ich autorzy omawiali zagadnienia, w których specjalizuje się pismo, z wykorzystaniem metod właściwych różnym dziedzinom humanistyki, zwłaszcza humanistyki stosowanej, stale pamiętając, że tym, co spośród innych czasopism naukowych wyróżnia „Napis”, jest przede wszystkim literatura okolicznościowa i użytkowa oraz interdyscyplinarne podejście do tematów $\mathrm{z}$ tego kręgu. W środowisku naukowym pismo stawało się bowiem coraz bardziej rozpoznawalne w tym właśnie aspekcie.

Należy w tym miejscu zwrócić również uwagę na to, że rozrastały się w ciągu tych lat działy naszego rocznika, co w efekcie doprowadziło do uporządkowania zawartych w nim rozpraw, studiów i materiałów źródłowych. Droga ta prowadziła od Rozpraw i Rozpraw i materiatów oraz Recenzji i omówień po ich uzupełnienie i wzbogacenie przez działy Pasje i potyczki edytorskie i tekstologiczne oraz Varia. Członkowie redakcji i Rady Naukowej dążyli do tego, by w ostatnim z wyżej wymienionych działów znalazły się przede wszystkim artykuły wiążące się z tematem głównym danego numeru.

Znaczące są też niektóre ważne elementy współtworzące atrakcyjną postać typograficzną roczników „Napisu”, które zachęcają do lektury swym wdziękiem i subtelnym dostosowaniem do głównego tematu. We wcześniejszych latach bardzo inspirujące okładki nawiązujące do myśli przewodniej danego numeru pisma projektował głównie Jacek Wójcicki (zastępca redaktora naczelnego czasopisma), wykorzystując ze znawstwem i spokojną elegancją historyczne źródła ikonograficzne. Niekiedy były to „znaki” niemal symboliczne, zwłaszcza dla badaczy dawnej książki, z którymi spotykali się, obcując z typografią tych druków, ale też szerzej nieznane, a dopiero na skutek tych wyborów projektodawcy zapadające w pamięć. Jacek Wójcicki wykorzystywał bowiem także źródła emanujące ekspresywnością (niekiedy z pominięciem tabu), reprezentujące jeden z możliwych sposobów podejścia do tematu. Od 2009 roku redakcja rozpoczęła owocną współpracę z dr Katarzyną Stanny z Akademii Sztuk Plastycznych w Warszawie, zwłaszcza że realizowane 
z pasją projekty okładek były współbieżne z jej zainteresowaniami naukowymi i artystycznymi. Katarzyna Stanny kieruje również projektami graficznymi, w efekcie których wyróżnione prace studentów Wydziału Sztuki Mediów warszawskiej ASP $\mathrm{w}$ postaci kolorowych wkładek związanych z przewodnim tematem kolejnych tomów pisma ukazują się w na łamach „Napisu” od 2012 roku (równolegle udostępniane są na stronie internetowej pisma jako materiał doskonale współgrający $z$ tematyką zamieszczanych tam artykułów). Prace te wzbogacają pismo, stanowią interesujący materiał artystyczny, wykorzystujący różne techniki (grafika, fotografia, również z wykorzystaniem artystycznej reprodukcji zdjęć archiwalnych); dają odbiorcom możliwość kontaktu ze sposobem wizualnego odbioru zagadnienia monograficznego danego numeru przez młodych adeptów sztuki.

Nad kształtem edytorsko-technicznym pisma oraz jego obecnością w przestrzeni cyfrowej czuwają: Michał Wysocki, który jest osobą odpowiedzialną za stronę www rocznika (a także autorem jej koncepcji graficznej), Martyna Sabała oraz Lidia Bakensztos wprowadzające artykuły z danego numeru do Repozytorium Cyfrowego Instytutów Naukowych (RCIN), Paweł Osial - projektodawca makiety i układu tekstu (layoutu); za angielską wersję streszczeń odpowiada tlumaczka Maria Helena Żukowska (współpracująca z nami od dwóch lat; w latach 20I5-20I7 funkcję tę pełniła śp. Olga Pieńkowska-Kordeczka), zaś za skład i łamanie - Helena Dziurnikowska oraz Michał Wysocki. Do zespołu redakcyjnego dołączyli niedawno Aleksandra Błasińska (od roku 2015), Andrzej P. Lesiakowski (w latach 20I7-20I8) oraz Kamil Dźwinel (od roku 2019).

Aktualny, jubileuszowy rocznik czasopisma „Napis” zawiera siedem artykułów w dziale Rozprawy i materiaty. Dział otwiera praca Marioli Jarczykowej, badaczki rodu Radziwiłłów birżańskich, która tym razem podjęła temat funeraliów Radziwiłłowskich z XVII wieku pisanych na zamówienie w kontekście ważnego zagadnienia „sponsorowanej pochwały” jako zjawiska obyczajowego, a zarazem kulturalno-literackiego literatury dawnej. Rozprawa Michała Kurana jest prezentacją sposobów upamiętniania czynów i cnót rycerskich obrońców ojczyzny przez Fabiana Birkowskiego w jego kazaniach funeralnych, które to sposoby zostały szczegółowo rozważone, z naciskiem na chwalone wartości, ale i na erudycję utalentowanego kaznodziei. Krystyna Maksimowicz natomiast w swej rozprawie ukazała źródła poetyckiej legendy Kajetana Sołtyka, odsłaniając nieznane dotąd (lub znane jedynie fragmentarycznie) teksty wierszy okolicznościowych powstałych w latach I767-I773 lub ich wątki, dotyczące osoby biskupa, wywiezionego podczas sejmu i767 roku do Kaługi wraz z innymi senatorami i jednym z posłów na sejm, co było formą nacisku Rosji na pozostałych obradujących i odbiło się szerokim echem w literaturze okolicznościowej. Interesujące są dalsze prezentacje i omówienia: 
przejawów literackiego hołdu poetów galicyjskich dla Józefa Dunina Borkowskiego w artykule Tadeusza Półchłopka oraz Pieśni o księciu Józefie Artura Oppmana, stanowiących cykl utworów przeznaczonych dla księcia Józefa Poniatowskiego jako narodowego bohatera, w rozprawie Romana Magrysia. Rodzajem hołdów dla szczególnie bliskich lub cenionych osób, które odeszły, są dokumenty literackie zebrane przez autorów kolejnych artykułów. Przedmiotem rozważań Julii Paprotnej są osobiste refleksje Rafała Malczewskiego o ojcu, Jacku Malczewskim, zaś Beata Garlej ukazuje poetykę stosowaną przez Romana Ingardena w jego wspomnieniach o fenomenologach i innych filozofach, których znał i cenił.

W części Pasje i potyczki edytorskie i tekstologiczne obserwujemy ciekawe przejście „między dawnymi a nowymi laty”. Dział ten rozpoczynają bowiem rozprawy reprezentujące rzetelne edytorstwo tradycyjne. Składa się na to: Bożeny Mazurkowej - edycja nieznanych listów Wenantego Tyszkowskiego do Radziwiłłów, poprzedzona wprowadzeniem do lektury oraz opatrzona przyjętymi zasadami transkrypcji i objaśnieniami, oraz artykuł Wojciecha Kaliszewskiego, w którym badacz zapoznaje nas $\mathrm{z}$ wierszowanym utworem wydobytym przezeń „z teki dawno zapomnianych rękopisów" i przedstawia argumenty na rzecz chronologii powstania tego tekstu. W należącym do historii drukarstwa i edytorstwa artykule Aleksandry Matykiewicz-Włodarskiej Efekt Lutra... można zapoznać się z rzeczowym, udokumentowanym źródłowo nakreśleniem radykalnej zmiany w sferze mediów drukowanych i komunikowania, która stanowiła długofalowy społeczny skutek reformacji. W artykułach Konrada Nicińskiego i Bartłomieja Szleszyńskiego rozważane są problemy edytorstwa cyfrowego tekstów, z bardzo dobrą znajomością tych trudnych zagadnień (między innymi dzięki udziałowi ich autorów w realizowanych w Instytucie Badań Literackich PAN projektach naukowych). To próba wytłumaczenia (przez Konrada Nicińskiego) trudności związanych z obecnością, miejscem i rodzajem przypisów w edycji cyfrowej (na przykład w omawianej korespondencji skamandrytów), które muszą być ściśle ograniczone rodzajowo, zwłaszcza w porównaniu $\mathrm{z}$ bardzo różnorodnymi rodzajami przypisów w edycji tradycyjnej (papierowej). Autor - z myślą o przyszłości - zwraca też uwagę na różnice w konstruowaniu przypisów w realizowanych w kraju projektach naukowo-badawczych, a także w zagranicznych bazach dotyczących utworów literackich innych narodów, odwołujących się do właściwych im źródeł. Wszystko to sprawia, że ujednolicenie rodzajów zapisów, a co za tym idzie: porozumienie nie jest łatwe, a może i niemożliwe. Sytuacja taka zachodzi przynajmniej na obecnym etapie rozwiązywania tych trudności. Bartłomiej Szleszyński natomiast przedstawia w swym artykule widome efekty i znaczenie prac nad znanym cyfrowym projektem edytorskim: Nową Panoramą Literatury Polskiej. Autor nie kryjąc problemów, jakie obecnie są związane z zarządzaniem 
projektowym w rodzimej humanistyce cyfrowej, dokładnie rozważa ich charakter i sugeruje możliwe sposoby ich pokonywania.

W Variach czytelnicy „Napisu” znajdą cztery zajmujące artykuły, w dużej mierze wiążące się z tematem przewodnim tego rocznika. Są to: „In articulo mortis”. O upamiętnianiu ostatnich stów (autorstwa Magdaleny Kreft); Rocznice narodowe jako medium pamięci kulturowej (pióra Magdaleny Piotrowskiej), Panegiryk „à rebours". Hugona Kottataja mentalna typografia Moskwy z I807/ I808 r., gdzie Marek Nalepa przedstawia duże fragmenty opisu Moskwy autorstwa Hugona Kołłątaja, wskazując na to, co pisarz i represjonowany przez zaborców działacz polityczny przedstawiał $\mathrm{w}$ swych zapisach jako rozwiązania pozytywne $\mathrm{w}$ tym mieście, co zaś wzbudzało w nim krytycyzm, niechęć, a nawet odrazę, niekiedy jako efekt stosunku autora do Rosji - autorytarnego mocarstwa, w którym „wielkość” znaczyła częstokroć „małośc” - a w tym także brak planu i estetycznego gustu. Dział ten kończy związany $z$ dominującym tematem i interdyscyplinarnym, a zarazem użytkowym profilem „Napisu” ciekawy artykuł Barbary Stelingowskiej Ekslibris - artystyczna personalizacja.

Po części zawierającej Varia zamieszczono prace studentów ASP w Warszawie wraz z komentarzami młodych autorów. Dzieła te wizualnie - jak „w soczewce” (zob. artykuły na ten temat w roczniku „Napis” XX) - prezentują sposób ich podejścia do objawów hołdu, laudacji i pamięci, pamiątki, upamiętniania, nie zawsze zgodny $z$ tradycyjnym ujęciem tych sygnałów pamięci zbiorowej, stanowiących jeden z najważniejszych czynników kulturotwórczych, spoiwo narodowej kultury.

Ostatnia część pisma Recenzje obejmuje w tym jubileuszowym numerze „Napisu” cztery naukowe recenzje książek opublikowanych w latach 2015-2019. Są to recenzje: książki Tadeusza Budrewicza Pogrzeby pisarzy polskich XIX wieku, napisana przez Bogdana Mazana, a zatytułowana Funeralne (nie)oczywistości i olśnienia; Marka Pąkcińskiego, zatytułowana Dtugi cień antysemityzmu, omawiająca publikację Małgorzaty Domagalskiej z 20I5 roku Zatrute ziarno. Proza antysemicka na tamach „Roli” (I883-I9I2), oraz recenzja Ewy Głębickiej poświęcona zbiorowej monografii wydanej w 2018 roku Rozczytywanie Dabrowskiej. Dział ten zamyka skrótowa prezentacja książki Stanisława Czerniaka Powrót zdarzeń, wydanej w 2019 roku, pióra Pawła Dybla pod tytułem Poezja świata, który stat się atrapa.

Tym wprowadzeniem pragniemy nie tylko przypomnieć osobę Janusza Maciejewskiego, założyciela naszego czasopisma, które odważył się (już w początkach lat dziewięćdziesiątych XX wieku!) poświęcić wyłącznie literaturze okolicznościowej i użytkowej, wówczas traktowanej marginalnie, a obecnie - w pierwszych dekadach XXI stulecia - stanowiącej przedmiot licznych edycji krytycznych, temat fascynujących dociekań, analiz i interpretacji, odkrywających dzięki tej nobilitacji 
nieznane dotąd przestrzenie narodowego piśmiennictwa - od doby staropolskiej po XXI wiek. Teraz wiemy, że piśmiennictwo będące reakcją na bieżące wydarzenia polityczne i literatura rejestrująca drobne realia życia codziennego, to elementy niezbędne dla całościowego widzenia kultury danej epoki w całej jej barwności i skomplikowaniu.

Pamiętając o zasługach i niepospolitej osobowości twórcy „Napisu”, nie zapominamy też o wkładzie pracy i twórczego wysiłku wielu osób, które złożyły się na kształt tego wieloletniego interdyscyplinarnego przedsięwzięcia - Profesora Janusza Tazbira, wielkiego przyjaciela rocznika, członków redakcji i Rady Naukowej, zespołu licznych współpracowników (których nie zdołano tu wszystkich wymienić). Ich badawcza ciekawość, intelektualna rzetelność i cierpliwa praca warunkują istnienie i ciągły rozwój rocznika, który od swych narodzin został pomyślany jako forum wymiany myśli między autorami reprezentującymi różne pokolenia, dyscypliny i kierunki badań, połączonymi zainteresowaniem obszarami trzecimi literatury, a zwłaszcza piśmiennictwem okolicznościowym i użytkowym.

Przede wszystkim zaś - w imieniu członków Redakcji oraz własnym - zapraszam do lektury naszego XXV tomu jubileuszowego Hotd, laudacja, pamiatka w literaturze $i$ kulturze. Razem $z$ autorami rozpraw, studiów, artykułów, edycji zawartych $\mathrm{w}$ dwudziestu pięciu tomach czasopisma oraz oceniającymi te prace recenzentami, z twórcami recenzowanych na naszych łamach książek oraz wszystkimi współpracownikami dbającymi o kształt edytorski i typograficzny „Napisu”, a także z sympatykami periodyku - świętujmy nasze ćwierćwiecze!

BARbara Wolska 